A high S.G.O.T. level may occur in status asthmaticus in the absence of myocardial infarction.

We are indebted to members of the United Cardiff Hospitals for criticism; to Dr. D. M. D. Evans, consultant pathologist ; and to members of his department of chemical pathology at St. David's Hospital, particularly to Mr. J. Clarke, F.I.M.L.T., and K. W. Davies, B.Sc., Ph.D., for transaminase estimations.

\section{REFERENCES}

Asvall, J. E. (1960). Scand. F. clin. Invest., 12, 247.

Baron, D. N., Alezander, C. P., Bell, J. L., and Oakley, C. M. (1958). Quart. F.' Med., 27, 533.

Becker, E. L. (1958). F. Allergy, 29, 191.

Bruce, R., Todd, J. K., and LeDune, L. (1958). Brit. med. 7., 2, 1125.

Chinsky, M., Shmagranoff, G. L., and Sherry, S. (1956). f. Lab. clin. Med., 47, 108.

Wolf, R. J., and Sherry, S. (1957). Amer. F. med. Sci., 233, 400.

Colldahl, H. (1943). Acta physiol. scand., Suppl. No. 8.

- (1960). Acta med. scand., 166, 399.

(1960). Acta med. scand., 166, 399.

York, October 1961. Amsterdam, Excerpta Medica Foundation, International Congress Series, 42, 25. International Congress Series, 42,
1121. A., Rowell, N. R., and Smith, A. J. (1958). Brit. med. F., 2,

Feldman, R. (1962). Ann. intern. Med., 57, 29.
Fragge, R. G., Kopel, F. B., and Iglauer, A. (1960). Ibid., 52, 1042. Gavasto, F., Pileri, A., and Brusca, A. (1957). Biochim. biophys. Acto (Amst.), 24, 250.

Godlowski, Z. Z., Calandra, J. D., and Baron, H. J. (1962). Ann. Allergy, $20,437$.

Helander, E., Lindell, S. E., Söderholm, B., and Westling, H. (1962). Acta allerg. (Kbh.), 17, 112.

Karmen, A. (1955). F. clin. Invest., 34, 131.

Lukas, D. S. (1951). ₹. Allergy, 22, 411 .

Reitman, S., and Frankel, S. (1957). Amer. F. clin. Path., 28, 56.

Rosen, F., Roberts, N. R., Budnick, L. E., and Nichol, C. A. (1958) Science, 127, 287.

Rudolph, L. A., Schaefer, J. A., Dutton, R. E., and Lyons, R. H. (1957). 7. Lab. clin. Med., 49, 31 .

Schiller, I. W., and Lowell, F. C. (1954). F. Allergy, 25, 364.

Sherlock, S. (1951). Brit. Heart f., 13, 273.

Sodi-Pallares, D., and Calder, R. M. (1956). New Basis of Electrocardiography, p. 244. Mosby, St. Louis, Mo.

Tickner, A., Mier, P. D., and McCabe, M. P. (1961). Brit. 7. Derm., 73, 180 .

Ungar, C., and Hyashi, H. (1958). Ann. Allergy, 16, 542.

Vickers, C. F. H. (1961). Brit. F. Derm.; 73, 185.

West, M., Gelb, D., Pilz, C. G., and Zimmerman, H. J. (1961). Amer. 7. med. Sci., 241, 350 .

Williams, D. A. (1963). Chest Dis. Index, 18, 95.

Williams, M. H., and Zohman, L. R. (1960). Amer. Rev. resp. Dis., 81, 173 .

Wroblewski, F. (1959). Amer. F. Med., 27, 911.

- and La Due, J. S. (1955). Ann. intern. Med., 43, 345.

- (1956a). Proc. Soc. exp. biol. (N.Y.), 91, 569. (1956b). F. Amer. med. Ass., 160, 1130.

\title{
A Survey of Antibodies to Respiratory Syncytial Virus in the Population*
}

\author{
M. H. HAMBLING, $\dagger$ M.D., DIP.BACT.
}

Brit. med. F., 1964, 1, 1223-1225

The respiratory syncytial (R.S.) virus has been shown to be an important cause of respiratory disease in young children and can account for at least one-fifth of the serious respiratory illnesses of infants (Chanock et al., 1961 ; McClelland et al., 1961 ; Adams et al., 1963). In adults the virus appears to be associated with a much less severe respiratory illness (Johnson et al., 1961, 1962). Presumably if infection with the virus is widely prevalent in children, serological studies on persons in the older age groups should reveal a high incidence of past infection. Few studies of this nature have been reported, although a small survey on the incidence of complement-fixing (C.F.) antibody, mainly in members of the younger age-groups, was described by Moss et al. (1963). During the past three years many sera have been examined for C.F. and neutralizing antibodies to the "Long" strain of R.S. virus. The following report contains the results of such tests on sera collected from persons of all age-groups and from umbilical cord blood.

\section{Materials and Methods}

Sera.-The 329 samples of serum examined were collected for various investigations from patients in hospitals during the period October 1960 to March 1962. Most of these attended the out-patient departments, but some, especially in the younger age-groups, were in-patients. None of them was considered to be suffering from acute respiratory illness when the serum was collected. They were divided by age into eight groups, with an additional group for sera from umbilical cord blood.

Virus strain.-The "Long" strain of R.S. virus was used for the preparation of C.F. antigen and infective virus suspen-

\footnotetext{
* This paper formed part of a thesis approved by the University of London for the degree of M.D.
}

+ Virus Reference Laboratory, Colindale, London. sions. The original isolation of this strain from a child with lower respiratory disease was reported by Chanock et al. (1957).

\section{Serological Tests}

Neutralization.-Serial fourfold dilutions of serum, inactivated at $56^{\circ} \mathrm{C}$. for 30 minutes, were made in SM 199 containing $0.09 \%$ sodium bicarbonate. At each dilution $0.5 \mathrm{ml}$. was mixed with an equal volume of virus suspension containing an estimated $100 \mathrm{TCD}_{50} / 0.1 \mathrm{ml}$. After holding at room temperature for one hour, $0.2 \mathrm{ml}$. of serum-virus mixture was inoculated into each of four HeLa culture tubes which contained $0.8 \mathrm{ml}$. of maintenance medium (SM 199 with $5 \%$ heatinactivated rabbit serum, $0.22 \%$ sodium bicarbonate, and antibiotics). A virus titration and control cultures of virus, serum, and tissue were included in each batch of tests. Cultures were incubated at $36-37^{\circ} \mathrm{C}$. in stationary racks. Cultures were examined microscopically for characteristic cytopathic effect (C.P.E.) The extent of the cell sheet affected by C.P.E. was estimated visually and recorded as \pm (occasional scattered areas of C.P.E.), $+(25-50 \%),++(50-75 \%)$, and $+++(75-100 \%)$. Final readings were made two days after the virus controls inoculated with $100 \mathrm{TCD}_{50}$ showed +++ C.P.E. Neutralization was considered to have occurred in those cultures in which the + C.P.E. was inhibited. The virus titration indicated that the actual dose of virus used in the tests was within the range 32-320 $\mathrm{TCD}_{50} / 0.1 \mathrm{ml}$. Fifty per cent. serum neutralization end-points were calculated by the method of Reed and Muench (1938), and titres are given as the reciprocal (expressed in logarithms to the base 10) of the initial serum dilution.

Complement-fixation.-Antigen was prepared from HeLa cell cultures grown in medical prescription bottles and maintained on a medium of SM 199 containing $5 \%$ heat-inactivated 
rabbit serum, $0.22 \%$ sodium bicarbonate, and antibiotics. After inoculation with the virus the cultures were incubated at $36-37^{\circ} \mathrm{C}$. until $75-100 \%$ of the cell sheet showed C.P.E. The cultures were then frozen and thawed three times and the fluid was centrifuged at approximately $1,000 \mathrm{~g}$ for 15 minutes; the supernatant fluid was used as C.F. antigen. The optimum dilution for use was determined by a chessboard titration against a positive human antiserum. The technique for performing the tests was based on that described by Pereira (1956), in which "Perspex" plates, a five-volume $(0.1 \mathrm{ml}$./vol.) test, and overnight fixation were used. Titres are expressed as the reciprocal of the highest initial serum dilution giving $75 \%$ or greater fixation.

\section{Results}

Incidence of Complement-fixing Antibodies.-Examination of 329 sera, from all age-groups, for C.F. antibodies showed that $233(71 \%)$ had antibodies at a dilution of $1 / 4$. The age distribution and details of the antibody titres are given in Table I. Although only a small number of the specimens examined were from very young children it was evident that the incidence of C.F. antibodies increased rapidly after the age of 1 year. The age-group 6 months to under 2 years contained only $23 \%$ positive sera in contrast to $66 \%$ positive in those aged $2-4$ years. In all the older groups at least two-thirds of the sera tested had antibodies, with the highest proportion ( $84 \%$ ) in age-group 15-29 years. Cord sera had a high incidence of antibodies similar to that in the child-bearing age-groups.

TABLE I.-Age Distribution of R.S. Complement-fixing and Neutralizing Antibodies

\begin{tabular}{|c|c|c|c|c|c|c|c|c|c|c|}
\hline \multirow{3}{*}{$\begin{array}{c}\text { Age- } \\
\text { group } \\
\text { in } \\
\text { Years }\end{array}$} & \multicolumn{5}{|c|}{ Complement-fixing Antibodies } & \multicolumn{5}{|c|}{ Neutralizing Antibodies } \\
\hline & \multirow{2}{*}{$\begin{array}{c}\text { No. } \\
\text { of } \\
\text { Samples } \\
\text { Tested }\end{array}$} & \multicolumn{3}{|c|}{ Titre } & \multirow{2}{*}{$\begin{array}{c}\% \\
\text { with } \\
\text { Titre } \\
\geqslant 4\end{array}$} & \multirow{2}{*}{$\begin{array}{c}\text { No. } \\
\text { of } \\
\text { Samples } \\
\text { Tested }\end{array}$} & \multicolumn{3}{|c|}{$\begin{array}{c}\text { Titre } \\
\left(\log _{10}\right)\end{array}$} & \multirow{2}{*}{$\begin{array}{c}\% \text { with } \\
\text { Neut. } \\
\text { Titre } \\
\geqslant 1\end{array}$} \\
\hline & & $<4$ & $4-16$ & $\mid \geqslant 32$ & & & $<1$ & $|1-1 \cdot 8|$ & $\mid \geqslant 1.9$ & \\
\hline $\begin{array}{l}\text { Cord } \\
\text { blood }\end{array}$ & 43 & 4 & 20 & 19 & 91 & 20 & 0 & 13 & 7 & 100 \\
\hline $\begin{array}{c}<\frac{1}{2} \\
1- \\
1 \\
2-4 \\
5-14 \\
15-29 \\
30-49 \\
50+\end{array}$ & $\begin{array}{l}12 \\
13 \\
13 \\
50 \\
50 \\
50 \\
48 \\
50\end{array}$ & $\begin{array}{r}5 \\
12 \\
8 \\
17 \\
14 \\
8 \\
12 \\
16\end{array}$ & $\begin{array}{r}6 \\
0 \\
2 \\
15 \\
21 \\
27 \\
22 \\
17\end{array}$ & $\begin{array}{r}1 \\
1 \\
3 \\
18 \\
15 \\
15 \\
14 \\
17\end{array}$ & $\begin{array}{l}58 \\
8 \\
38 \\
66 \\
72 \\
84 \\
75 \\
68\end{array}$ & $\begin{array}{l}10 \\
12 \\
11 \\
23 \\
26 \\
32 \\
23 \\
25\end{array}$ & $\begin{array}{l}4 \\
9 \\
6 \\
8 \\
4 \\
4 \\
2 \\
0\end{array}$ & $\begin{array}{r}6 \\
1 \\
2 \\
5 \\
12 \\
24 \\
12 \\
11\end{array}$ & $\begin{array}{r}0 \\
2 \\
3 \\
10 \\
10 \\
4 \\
9 \\
14\end{array}$ & $\begin{array}{r}60 \\
25 \\
45 \\
65 \\
85 \\
88 \\
91 \\
100\end{array}$ \\
\hline Total & 329 & 96 & 130 & 103 & 71 & 182 & 37 & 86 & 59 & 80 \\
\hline
\end{tabular}

Incidence of Neutralizing Antibodies.-Titrations of 182 of the 329 samples of serum showed that $145(80 \%)$ had neutralizing antibodies at a dilution of $1 / 10$. The age distribution and details of the antibody titres are given in Table $I$. The incidence of neutralizing and C.F. antibodies followed a similar pattern except in the older age-groups. Of the 80 sera examined from patients aged 15 years and older, 74 (93\%) had neutralizing antibodies.

Sex Distribution of C.F. Antibodies.-As shown in Table II, the number of males and females whose sera contained C.F.

TABLE II.-Complement-fixing Antibodies to R.S. Virus. Showing Sex Distribution of Complement-fixing Antibodies to R.S. Virus in 286 Samples of Serum from Persons in All Age-groups

\begin{tabular}{c|c|c|c|c}
\hline \multirow{2}{*}{$\begin{array}{c}\text { Age-group } \\
\text { (in Years) }\end{array}$} & \multicolumn{2}{|c|}{ Male } & \multicolumn{2}{|c}{ Female } \\
\cline { 2 - 5 } \cline { 4 - 5 } & $\begin{array}{c}\text { No. } \\
\text { Tested }\end{array}$ & $\begin{array}{c}\text { C.F. Titre } \\
\text { Positive }\end{array}$ & $\begin{array}{c}\text { No. } \\
\text { Tested }\end{array}$ & $\begin{array}{c}\text { C.F. Titre } \\
\text { Positive }\end{array}$ \\
\hline $\begin{array}{c}0-14 \\
15-50 \text { and over }\end{array}$ & $\begin{array}{c}87 \\
69\end{array}$ & $\begin{array}{c}49(56 \%) \\
51(74 \%)\end{array}$ & $\begin{array}{c}51 \\
79\end{array}$ & $\begin{array}{c}33(65 \%) \\
61(77 \%)\end{array}$ \\
\hline
\end{tabular}

antibodies did not differ significantly, which suggests that both sexes are equally susceptible to the virus.

Relation of C.F. to Neutralizing Antibody Titres.-Sera from 182 patients were titrated for neutralizing and C.F. antibodies. The titrations were begun at a serum dilution of $1 / 4$ for C.F. and $1 / 10$ for neutralization. If antibodies were not detected at these dilutions the sera were regarded as having no antibodies. The results were:

\begin{tabular}{|c|c|c|c|}
\hline $\begin{array}{l}\text { Neutralizing antibodies present } \\
\text { C.F. antibodies present }\end{array}$ & 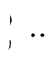 & & 116 sera \\
\hline $\begin{array}{l}\text { Neutralizing antibodies present } \\
\text { C.F. antibodies absent }\end{array}$ & & $\cdots$ & 29 sera \\
\hline $\begin{array}{l}\text { Neutralizing antibodies absent } \\
\text { C.F. antibodies present }\end{array}$ & 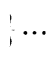 & $\cdots$ & 8 sera \\
\hline $\begin{array}{l}\text { Neutralizing antibodies absent } \\
\text { C.F. antibodies absent }\end{array}$ & & & 29 \\
\hline
\end{tabular}

Of the 29 sera in which both neutralizing and C.F. antibodies were absent, 23 were from children aged $0-4$ years. The age distribution of these 182 sera is shown in Table I and the relation between C.F. antibody and neutralizing antibody titres is shown in the Chart.

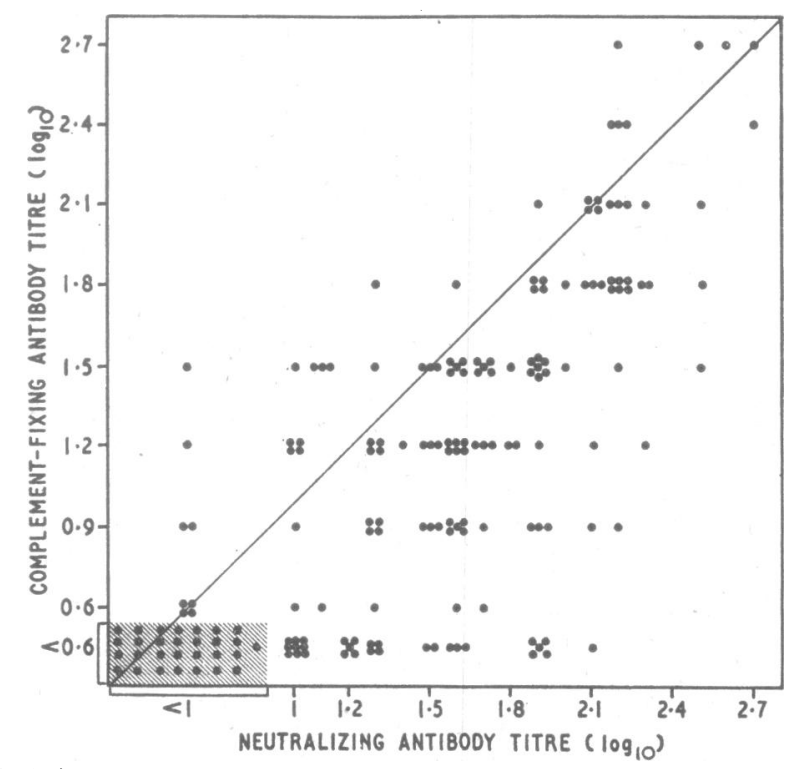

Relation between complement-fixing and neutralizing antibody titres to R.S. virus in 182 samples of serum.

\section{Discussion}

The incidence of both C.F. and neutralizing antibodies followed a similar pattern in the younger age-groups. The incidence was lowest in those aged 6-11 months and increased rapidly until at 5 years old over $70 \%$ of the children investigated had both types of antibody. The findings in the lower age-groups were essentially similar to those reported by Moss et al. (1963). It was of interest that the incidence of neutralizing antibodies continued to increase with age so that all the serum samples from persons over 50 years old had antibodies. In contrast, the incidence of C.F. antibodies reached a peak in the 15-29 age-group followed by a slight decrease as age increased. This decrease in the older age-groups could be attributed to a lower rate of reinfection, either associated with an increased state of immunity due to repeated infections in earlier years or to less close contact with young children. The high incidence $(75 \%)$ of C.F. antibody in all persons older than 5 years suggests that either the antibody persists for many years or reinfection with R.S. virus or an antigenically related agent occurs in adult life. In a study of men entering the Marine Corps, it was demonstrated (Johnson et al., 1962) that natural reinfection with R.S. virus could occur despite the presence of antibodies in the serum. Previously Johnson et al. (1961) had shown that male adult volunteers aged between 21 and 35 who had antibodies in their serum could be infected with the virus. They suggested that these antibodies were probably responsible for the mild nature of the illnesses observed. 
If antibody to R.S. virus was detectable by the methods used, the majority (76\%) of persons had both neutralizing and C.F. antibodies in their serum, as is shown in the Chart. Of the 29 sera which did not contain either C.F. or neutralizing antibodies, $23(79 \%)$ were from children aged $0-4$ years.

The high incidence of antibodies in umbilical-cord serum which was similar to that of the child-bearing age-groups indicated the transplacental passage of antibodies.

\section{Summary}

Examination of 329 samples of serum from all age-groups was made to detect antibodies to the respiratory syncytial virus. At the age of 5 years, and in all older age-groups, over $66 \%$ of the sera contained both neutralizing and complement-fixing antibodies. The lowest incidence of antibodies was in the 6 months to 1-year age-group. A high incidence of infection with respiratory syncytial virus in the population was indicated by the finding of neutralizing antibody in $93 \%$ of sera from persons over 15 years of age.

\section{REFBRBNCBS}

Adams, M. O., Thompson, K. M., and Tobin, J. O'H. (1963). Arch. ges. Virusforsch., 13, 268.

Chanock, R. M., Kim, H. W., Vargosko, A. J., Deleva, A., Johnson, K M., Cumming, C., and Parrot, R. H. (1961). 7. Amer. med. Ass., 176, 647 .

- Roizman, B., and Myers, R. (1957). Amer. F. Hyg., 66, 281.

Johnson, K. M. 'Bloom, Mufson, M. A., and Chanock, R. M (1962). New Engl. J. Med., 267, 68.

Chanock, R. M., Rifkind, D., Kravetz, H. M., and Knight, V. (1961). f. Amer. med. Ass., 176, 663.

McClelland, L., Hilleman, M. R., Hamparian, V. V., Ketler, A., Reilly, C. M., Cornfeld, D., and Stokes, J., jun. (1961). New Engl. J. Med. 264, 1169.

Moss, P. D., Adams, M. O., and Tobin, J. O'H. (1963). Lancet, 1, 298.

Pereira H G. (1956). 7. Path Bact., 72, 105

Reed, L. J., and Muench, H. (1938). Amer. F. Hyg., 27, 493.

\section{Incidence of de Quervain's Thyroiditis: Ten Cases from One General Practice}

The patient with de Quervain's thyroiditis usually presents with a painful thyroid swelling of rapid onset. In severe cases, malaise, fever, fatigue, nervousness, and loss of weight are found, but the patient rarely becomes hypothyroid unless she is mistakenly treated by thyroidectomy. The characteristic finding on examination is the firm or hard, very tender goitre. In most cases the whole gland is involved, but in a small proportion-7 out of 38 in Crile and Rumsey's (1950) series-the swelling remains confined to one lobe. The erythrocyte sedimentation rate is raised and hypochromic anaemia is common, but the leucocyte count remains normal. Thyroid antibodies either are absent or are present in a very low titre. The diagnosis can be confirmed by radioiodine studies, which show complete suppression of radioiodine uptake when the whole gland is involved, and areas of reduced uptake when only one part is affected. Needle biopsy shows a picture of acinar destruction, fibrosis, and infiltration with multinucleate giant cells, lymphocytes, and plasma cells.

De Quervain's thyroiditis is quite distinct from autoimmune thyroiditis, in which thyroid pain and tenderness are unusual, the onset of the illness is less rapid, the patient is often hypothyroid, radioiodine uptake is normal or raised, and thyroid autoantibodies are present in a high titre. Because it has many features in common with virus infections, de Quervain's thyroiditis is thought to be due to a virus. Evidence of mumps virus infection has been found in one outbreak in Israel (Eylan et al., 1957) and in a single case in Britain (Felix-Davies, 1958). In other cases, however, tests for virus antibodies have been negative.

Judging by the available evidence, de Quervain's thyroiditis seems to be rare in Britain. Doniach et al. (1960) saw only four cases in three years at the Middlesex Hospital, and Meachim and Young (1963) could find only two examples in surgical material from 1,282 patients with primary thyroid disease in

* General Practitioner, Stratford on Avon.
Sheffield. It has been suggested, however (British Medical fournal, 1963), that many mild cases may be misdiagnosed or treated at home. Several authors have reported a high incidence of diagnostic errors in this disease. In Crile and Rumsey's (1950) series errors were found in 15 out of 38 cases, the commonest mistaken diagnoses being nodular goitre, thyroid carcinoma, and haemorrhage into an adenoma. The diagnosis may be obscured by an asymptomatic goitre, by anaemia, or by minimal or absent febrile symptoms (Skillern et al., 1956). The pain on swallowing may lead to a mistaken diagnosis of pharyngitis (Vanderlinde and Milne, 1960).

The purpose of this paper is to describe 10 cases of de Quervain's thyroiditis seen in one general practice during the past nine years. During the same period my records show 22 new cases of thyrotoxicosis, eight of hypothyroidism, and one of autoimmune thyroiditis. The practice National Health Service list was 5,943 in 1954 and 7,891 in 1963.

\section{Case Histories}

The main clinical and pathological features are summarized in the Table. All the patients except one (Case 3) presented with pain in the front of the neck, and in all except this patient the gland was firm or hard, and very tender. In Case 1 the hardness of the gland led to a mistaken diagnosis of carcinoma of the thyroid. In Cases $1,2,5,6,8$, and 9 the whole gland was enlarged ; in Cases 3, 4, 7, and 10 the swelling was confined to one lobe. The following case reports illustrate the course of the disease.

Case 8.-A housewife aged 40 complained of lassitude and pain in the front of the neck of six weeks' duration. She had not felt feverish. The thyroid was diffusely enlarged, firm, and tender. Two weeks after the first examination the pain was less severe and the gland smaller; and in another two weeks the tenderness had gone. Four weeks later she was feeling well, but the thyroid was still firmer than normal. During the next month she contracted 